\title{
Faktor-Faktor Pendorong Petani dalam Memilih Benih Kelapa Sawit (Elaeis guineensis) Bersertifikat dan Nonsertifikat
}

\author{
Laura Juita Pinem ${ }^{\mathrm{a}}$, dan Mirna Pratiwi ${ }^{\mathrm{b}}$ \\ ${ }^{a}$ Fakultas Agroteknologi, Universitas Prima,Indonesia.Email: laurajuitapinem@unprimdn.ac.id \\ ${ }^{b}$ Fakultas Agroteknologi, Universitas Prima, Indonesia.Email: myrnapratiwi88@gmail.com
}

\section{Article Info}

\section{Article history:}

Received 8 Desember 2019

Received in revised form 13 Desember 2019

Accepted 28 Desember 2019

DOI:

https://doi.org/10.32938/ag.v5i1.853

Keywords:

Kelapa Sawit

Benih

\begin{abstract}
Abstrak
Saat ini petani kelapa sawit masih banyak mengounakan benih kelapa sawit nonsertifikat termasuk petani yang berada di Kabupaten Asahan. Penggunaan benih nonsertifikat menimbulkan kerugian yang besar,karena produktivitas tanaman dari benih nonsertifikat lebih kecil dari benih bersertifikat. Penelitian ini bertujuan untuk mengidentifikasi karakteristik petani, menganalisis tahapan proses pengambilan keputusan pembelian petani dalam memilih benih bersertifikat dan non sertifikat, dan menganalisis faktor-faktor yang mempengaruhi proses pengambilan keputusan pembelian petani dalam memilih benih kelapa sawit bersertifikat dan nonsertifikat di Kabupaten Asahan. Penelitian ini dianalisis dengan bantuan 100 responden. Metode yang digunakan dalam penelitian ini adalah analisis deskriptif dan regresi logistik. Hasil dari analisis faktor membentuk lima variabel yang mempengaruhi pengambilan keputusan petani dalam memilih benih, yaitu variabel umur, variabel ketahanan benih terhadap hama dan penyakit tanaman, variabel lama berusaha tani, variabel luas lahan serta variabel akses benih.
\end{abstract}

\section{Pendahuluan}

Pembangunan pertanian tanpa didukung oleh pembangunan pembenihan akan mempengaruhi kontribusi terhadap produktivitas tanaman (Ditjetbun,2019). Semakin tinggi mutu benih yang digunakan maka semakin besar produksi yang dihasilkan. Sertifikat benih merupakan salah satu bentuk pembangunan pembenihan. Sistem pengawasan mutu dan sertifikasi benih yang handal dapat melindungi keaslian varietas dan kemurnian genetik, baik yang diproduksi oleh produsen maupun yang digunakan oleh konsumen di lapangan agar sesuai dengan standar mutu benih yang berlaku. Benih yang bermutu tinggi diharapkan menjadi salah satu jaminan untuk meningkatkan produksi, produktivitas, dan mutu hasil pertanian yang berdaya saing, dan pada akhirnya bisa berdampak positif terhadap pendapatan dan kesejahteraan petani.

Kabupaten Asahan merupakan salah satu kabupaten di Sumatera Utara yang menempatkan kelapa sawit sebagai salah satu komoditas unggulan dengan luas lahan terluas untuk perkebunan yang dikelola rakyat yaitu $72.416 \mathrm{Ha}$. Hal ini juga menunjukkan bahwa banyak petani rakyat yang menggantungkan kehidupan mereka pada komoditas kelapa sawit. Ada sekitar 36.723 petani yang menggantungkan hidup pada komoditas ini. Tetapi produktivitas dari kelapa sawit yang dikelola oleh petani belum maksimal, hal ini ditunjukkan melalui data dari Direktorat Jenderal Perkebunan bahwa pada tahun 2016 Kabupaten Asahan dengan luas area kelapa sawit sebesar 72.416 hektar, produktivitas yang dapat dicapai adalah $3.721 \mathrm{~kg} / \mathrm{ha}$ sedangkan data dari lembaga yang sama menunjukkan bahwa di Sumatera Utara perkebunan yang dikelola oleh perkebunan swasta dan negeri bisa mencapai produktivitas $4.921 \mathrm{~kg} / \mathrm{ha}$. Salah satu alasan yang menjadi kemungkinan belum maksimalnya produktifitas kelapa sawit petani di Kabupaten Asahan adalah karena penggunaan benih palsu atau benih yang tidak terjamin mutunya. Hal senada telah dianalisis Kariyasa (2015), dalam jurnalnya mengatakan bahwa petani yang menggunakan benih bersertifikat mampu mengembalikan modal yang diinvestasikan lebih cepat jika dibandingkan dengan petani yang menggunakan benih non sertifikat.

Penggunaan benih yang tidak tepat di Kabupaten Asahan merupakan satu penyebab produktivitas kelapa sawit yang dikelola oleh petani tidak menghasilkan produktifitas yang maksimal. Penggunaan benih dengan kualitas yang rendah bisa menyebabkan petani merugi dalam kurun waktu yang panjang karena kelapa sawit merupakan tanaman tahunan. Berdasarkan alasan tersebut, maka dapat dirumuskan beberapa pertanyaan yang menjadi dasar penelitian bagaimana persepsi petani kelapa sawit terhadap benih bersertifikat dan non sertifikat di Kabupaten Asahan, bagaimana tahapan proses pengambilan keputusan pembelian petani dalam memilih benih bersertifikat dan non sertifikat di Asahan, dan faktor-faktor apa saja yang mempengaruhi proses pengambilan keputusan pembelian petani dalam memilih benih bersertifikat dan non sertifikat di Kabupaten Asahan.

Kotler dan Amstrong (2016) membagi tahapan proses keputusan pembelian konsumen pada lima tahap, yaitu : (1) pengenalan masalah/kebutuhan; (2) pencarian informasi; (3) evaluasi alternatif; (4) keputusan pembelian;(5) pengambilan keputusan.

\section{Metode}

Penelitian ini dilaksanakan di Kabupaten Asahan, Sumatera Utara pada tahun 2019. Data yang diperoleh dalam penelitian ini merupakan data primer yang didapat dengan menggunakan kuisioner dan wawancara terhadap responden. Jumlah sampel yang digunakan dalam penelitian ini adalah 100 responden. Jumlah sampel ini didapat dengan merujuk kepada Rumus Slovin yang digunakan untuk menentukan ukuran minimal sampel yang dibutuhkan dari suatu populasi sehingga mendapatkan sampel yang mewakili populasi.

Teknik pengolahan dan analisis data yang digunakan adalah metode deskriptif kualitatif dan Regresi Logistik. Metode pengumpulan data yang dipakai pada penelitian ini adalah teknik angket (kuisioner). Setelah data terkumpul, data kemudian diolah dengan menggunakan Microsoft Excel 2010 dan SPSS VERSI 23.

Analisis deskriptif bertujuan menyajikan data mentah yang didapat dalam penelitian menjadi lebih mudah untuk dipahami dengan membentuknya menjadi informasi yang ringkas. Faktor-faktor yang mempengaruhi pengambilan keputusan pembelian petani dalam memilih benih bersertifikat dan non sertifikat didapat dengan menggunakan pendekatan model regresi logistik atau logit. Pada model ini dideskripsikan hubungan antara peubah terikat yang memiliki dua kategori atau lebih dengan satu atau lebih peubah bebas berskala kategori atau interval.

Responden pada penelitian ini dikategorikan dalam kelompok petani pengguna benih bersertifikat dan kelompok petani pengguna benih nonsertifikat Faktor-faktor yang mempengaruhi keputusan pembelian petani dalam memilih benih diduga dipengaruhi oleh faktor pendidikan, pengaruh pihak lain, umur, pengalaman usaha tani, luas lahan, status kepemilikan lahan, persepsi, ketahanan benih terhadap hama dan penyakit tanaman, harga benih, dan akses benih. Variabel-variabel bebas $\mathrm{x}$ akan berpengaruh terhadap variabel terikat $\mathrm{Y}$. Variabel terikat Y mempunyai dua kemungkinan nilai, yaitu 1 dan 0 . Nilai $Y=1$, berarti keputusan pembelian benih kelapa sawit bersertifikat sedangkan 0 berarti keputusan pembelian benih kelapa sawit non sertifikat. Model yang digunakan adalah sebagai berikut :
$\mathrm{Yi}=\alpha+\beta 1 \mathrm{X} 1+\beta 2 \mathrm{D} 1+\beta 3 \mathrm{X} 2+\beta 4 \mathrm{X} 3+\beta 5 \mathrm{X} 4+\beta 6 \mathrm{D} 2+\beta 7 \mathrm{D} 3+\beta 8 \mathrm{D} 4+\beta 9 \mathrm{X} 5$
$+\mathrm{e}$
Dimana :
Yi $\quad$ : Keputusan pembelian kelapa sawit
$\alpha \quad:$ Intersep
X1 : Pendidikan (tahun)
D1 : Dummy pengaruh pihak lain (1=adanya pengaruh, 0 tidak ada
pengaruh)
X2 : umur (tahun)
X3 : Pengalaman usahatani (tahun)
X4 : Luas Lahan (hektar)
D2 : Dummy persepsi (1= benih bersertifikat lebih baik dari nonsertifikat, $0=$ benih bersertifikat tidak lebih baik dari benih non sertifikat)
D3 : Dummy ketahanan benih terhadap hama dan penyakit tanaman $(1=$ tahan, $2=$ tidak tahan)
$\begin{array}{ll}\text { X5 } & : \text { Harga benih }(\mathrm{Rp} / \mathrm{kecambah}) \\ \mathrm{D} 4 & : \text { Dummy akses benih }(1=\text { mudah, } 0=\text { sulit })\end{array}$
$\begin{array}{ll}\mathrm{D} 4 & : \text { Dummy akses benih } \\ \mathrm{Bi} & \text { : Parameter peubah } \mathrm{Xi}\end{array}$
e $\quad:$ error/kesalahan

\section{Hasil dan Pembahasan}

\subsection{Karakteristik Petani Kelapa Sawit}

Karakteristik petani kelapa sawit diperlukan dalam penelitian ini untuk mengetahui sejumlah ciri atau sifat yang dimiliki oleh petani kelapa sawit dalam mengambil keputusan pembelian benih kelapa sawit serta faktor-faktor yang mempengaruhinya. Mengetahui karakterisktik dari petani merupakan salah satu informasi yang dibutuhkan produsen untuk menentukan segmentasi, target pasar dan positioning yang tepat (Kotler, 2016). Karakteristik responden yang digunakan dalam penelitian ini adalah usia, tingkat pendidikan, lama berusaha tani, luas lahan, status kepemilikan. Karakteristik ini menurut penelitian yang dilakukan Asih (2009) di Sulawesi mempunyai pengaruh terhadap ketrampilan petani dalam menjalankan usaha taninya. 
Usia petani pengguna benih kelapa sawit bersertifikat pada penelitian ini didominasi oleh petani yang berada pada rentang usia $>50$ tahun. Menurut Bakir dan Maning (1984), umur produktif untuk bekerja di negara-negara maju pada umumnya adalah 15-55 tahun. Hal ini menunjukkan bahwa petani responden berada pada usia produktif sehingga petani pada usia ini masih memiliki keinginan untuk mengembangkan usahanya. Hal yang sama juga ditunjukkan oleh usia petani pengguna benih nonsertifikat yang didominasi oleh petani yang berada pada rentang usia $>50$ tahun. Rentang usia yang dimiliki oleh petani merupakan rentang usia produktif yang mendorong petani untuk menghasilkan pendapatan sesuai dengan kebutuhan anggota keluarga.

Tingkat pendidikan yang dimiliki petani mempunyai pengaruh terhadap pola pola pikir dan daya nalar seseorang, biasanya seseorang yang mengenyam pendidikan cukup lama akan lebih rasional dalam bertindak dan menjalankan usahanya (Afrizon, 2012). Tingkat pendidikan yang dienyam oleh petani yang menggunakan benih bersertifikat sekitar 34 persen menikmati pendidikan sampai level SMA sedangkan petani yang menggunakan benih non sertifikat berada pada level pendidikan SD pada persentase 38 persen. Selain pendidikan, pengalaman berusaha tabi juga merupakan faktor pendukung bagi petani dalam meningkatkan ketrampilan dalam menjalankan usaha tani. Ditilik dari pengalaman dalam berusahatani, petani dengan benih sertifikat sekitar 30 persen sudah melakukan usahatani kelapa sawit lebih dari 20 tahun sedangkan 30 persen petani dengan benih nonsertifikat mengantungkan usahatani sebagai salah satu sumber penghasilnya selama 1-5 tahun. Lamanya berusahatani merupakan pengalaman bagi petani yang mencerminkan kegiatan dan ketrampilan dalam mengelola usahataninya. Pengalaman cukup yang dimiliki petani akan melatih kemampuan dan kematangan petani dalam mempertimbangkan setiap langkah keputusan yang berkaitan dengan usahatani kelapa sawit yang sedang dijalankan. Hal ini sesuai dengan penelitian yang dilakukan oleh Emiria (2014).

Selain capital dan tenaga kerja, lahan merupakan salah satu komponen dalam usahatani yang mempunyai peran penting. Besar kecilnya lahan mempengaruhi besar kecilnya pendapatan yang diperoleh dari usahatani (Emiria, 2014). Data yang didapat dari petani dengan penggunaan benih sertifikat menunjukkan bahwa sebanyak 44 persen petani mempunyai lahan sekitar 1-5 Ha sedangkan pada petani yang menggunakan benih nonsertifikat, persentase luas lahan dengan ukuran yang sama adalah $70 \%$. Berdasarkan luas lahan yang dimiliki oleh petani, petani mempunyai peluang untuk dapat berusahatani kelapa sawit dengan lebih baik sehingga produksi yang dicapai tinggi. Selain luas lahan, karakteristik status kepemilikan lahan yang dipakai petani dalam berusaha tani juga mempunyai kontribusi yang besar dalam menentukan pendapatan yang dihasilkan petani. Penelitian yang dilakukan di Kabupaten Asahan menunjukkan data bahwa baik petani yang menggunakan benih sertifikat maupun nonsertifikat mempunyai persentase yang sama dalam kepemilikan lahan, yaitu 100 persen. Semua petani tersebut mempunyai lahan sendiri untuk ditanami benih kelapa sawit sehingga memudahkan petani dalam mengolah lahan jtanpa harus memikirkan biaya sewa lahan. Karakteristik dari petani responden disajikan pada Tabel 1.

Tabel 1. Karateristik Petani Responden Kelapa Sawit

\begin{tabular}{|c|c|c|c|c|c|}
\hline \multirow[b]{2}{*}{ No } & \multirow[b]{2}{*}{ Karakteristik } & \multicolumn{2}{|c|}{ Petani Benih Sertifikat } & \multicolumn{2}{|c|}{ Petani Benih Non Sertifikat } \\
\hline & & Kategori & $\begin{array}{l}\text { Persentase } \\
(\%)\end{array}$ & Kategori & Persentase (\%) \\
\hline 1 & Usia & $>50$ & 26 & $>50$ & 38 \\
\hline 2 & Pendidikan & SMA & 34 & $\mathrm{SD}$ & 38 \\
\hline 3 & Luas Lahan & $0-5 \mathrm{Ha}$ & 44 & $0-5 \mathrm{Ha}$ & 70 \\
\hline 4 & $\begin{array}{l}\text { Lama Berusaha } \\
\text { Tani }\end{array}$ & $>20$ Tahun & 30 & 0-5 Tahun & 30 \\
\hline 5 & $\begin{array}{l}\text { Status } \\
\text { Kepemilikan }\end{array}$ & $\begin{array}{l}\text { Milik } \\
\text { Sendiri }\end{array}$ & 100 & $\begin{array}{c}\text { Milik } \\
\text { Sendiri }\end{array}$ & 100 \\
\hline
\end{tabular}

\subsection{Proses Pengambilan Keputusan}

Tahapan yang dianalisis dalam proses pengambilan keputusan petani dalam memilih benih kelapa sawit meliputi pengenalan kebutuhan, pencarian informasi, evaluasi alternatif, keputusan pembelian dan perilaku pasca pembelian (Kotler, 2016). Tahapan yang pertama yang dilakukan dalam proses pengambilan keputusan adalah tahap pengenalan kebutuhan (Tabel 2). Pada tahap ini, petani pengguna benih bersertifikat memutuskan untuk memakai benih dengan berbagai motivasi diantaranya 10 persen memilih karena benih mudah diperoleh di lapangan dan 82 persen memilih karena kualitas benih bagus . Di pihak lain, 64 persen petani benih nonsertifikat tetap memilih benih yang dipakainya dengan motivasi harga yang terjangkau oleh petani sedangkan sisanya memilih benih karena mudah diperoleh dan beranggapan bahwa benih yang dibeli mempunyai kualitas yang bagus. Selain motivasi pada tahap pengenalan kebutuhan juga dilihat manfaat yang diinginkan petani dari benih yang mereka pilih. Hampir semua petani memilih benih yang mereka pakai untuk meningkatkan produksi tanaman kelapa sawit yang mereka budidayakan di lahan mereka. Meningkatkan produksi merupakan salah satu cara petani untuk meningkatkan pendapatan dari lahan yang mereka kelola.

Tahap selanjutnya dalam pengambilan keputusan petani adalah pencarian informasi terhadap benih yang ingin dipakai. Pencarian informasi akan dilakukan oleh petani karena petani terdorong oleh kebutuhan akan benih sehingga petani akan mencari informasi yang lebih banyak berkaitan dengan benih. Perolehan informasi mengenai kelemahan dan keunggulan benih yang akan dipakai akan berpengaruh pada keputusan petani dalam memilih benih. Benih sertifikat yang dipilih oleh 60 persen petani dipilih berdasarkan informasi yang didapat dari petani lain/kelompok tani. Banyak petani percaya dengan informasi yang didapat dari petani lain/kelompok tani karena mereka bisa melihat langsung keunggulan dari benih yang dipakai. Sedangkan petan memilih menggunakan benih nonsertifikat sebesar 58 persen mendapatkan informasi dari toko pertanian/pedagang benih. Pencarian informasi pada pedagang benih yang tidak legal menjadi salah satu penyebab banyaknya petani menjadi korban penipuan benih. Tahap pencarian informasi dapat dilihat pada Tabel 3.

\begin{tabular}{|c|c|c|c|c|c|}
\hline \multirow[t]{2}{*}{ No } & \multirow[t]{2}{*}{ Uraian } & \multicolumn{2}{|c|}{ Petani Benih Bersertifikat } & \multicolumn{2}{|c|}{$\begin{array}{l}\text { Petani Benih } \\
\text { Nonsertifikat }\end{array}$} \\
\hline & & $\begin{array}{l}\text { Jumlah } \\
\text { Responden } \\
\text { (Orang) }\end{array}$ & $\begin{array}{l}\text { Persentase } \\
(\%)\end{array}$ & $\begin{array}{c}\text { Jumlah } \\
\text { Responden } \\
\text { (Orang) }\end{array}$ & $\begin{array}{c}\text { Persentase } \\
(\%)\end{array}$ \\
\hline \multirow{6}{*}{ 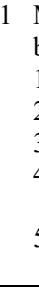 } & $\begin{array}{l}\text { Motivasi menggunakan } \\
\text { benih }\end{array}$ & & & & \\
\hline & 1. Harga terjangkau & - & - & 32 & 64 \\
\hline & 2. Mudah diperoleh & 5 & 10 & 10 & 20 \\
\hline & 3. Kualitas benih bagus & 41 & 82 & 8 & 16 \\
\hline & $\begin{array}{l}\text { 4. Memperoleh } \\
\text { keuntungan }\end{array}$ & - & - & - & - \\
\hline & $\begin{array}{l}\text { 5. Pemakaian } \\
\text { turun temurun }\end{array}$ & 4 & 8 & - & - \\
\hline \multirow[t]{5}{*}{2.} & Manfaat yang dicari & & & & \\
\hline & $\begin{array}{l}\text { a. Meningkatkan jumlah } \\
\text { produksi }\end{array}$ & 50 & 100 & 36 & 72 \\
\hline & $\begin{array}{l}\text { b.Menghemat biaya } \\
\text { produksi }\end{array}$ & - & - & 14 & 28 \\
\hline & $\begin{array}{l}\text { c. Meningkatkan } \\
\text { kualitas produksi }\end{array}$ & - & - & - & - \\
\hline & $\begin{array}{l}\text { d.Mengurangi terkena } \\
\text { HPT }\end{array}$ & a & - & - & - \\
\hline
\end{tabular}

Tabel 3. Tahap Pencarian Informasi

\begin{tabular}{ccccc}
\hline No Uraian & 'etani Benih & & Petani Benih \\
& 3ersertifikat & & Nonsertifikat \\
\cline { 2 - 5 } & Jumlah & Persentas & Jumlah & Perse \\
& Responden & e (\%) & Respon & ntase \\
& (Orang) & & den & $(\%)$ \\
& & & (Orang) & \\
\hline
\end{tabular}

$\begin{array}{lllll}\begin{array}{l}\text { Sumber Informasi } \\ \begin{array}{l}\text { a.Pengalaman diri } \\ \text { sendiri }\end{array}\end{array} & 9 & 18 & 2 & 4 \\ \begin{array}{l}\text { b. Toko pertanian/ } \\ \begin{array}{l}\text { c. pedagang benih } \\ \text { d. Petani/ kelompok } \\ \text { tani }\end{array}\end{array} & 11 & 22 & 29 & 58 \\ \text { e. Keluarga } & 30 & 60 & 19 & 38\end{array}$

Setelah mencari informasi dari sumber yang dipercaya petani kemudian petani akan masuk pada tahap evaluasi alternatif. Petani pada tahap evaluasi alternatif memilih kriteria-kriteria tertentu yang relevan dengan keinginan dan kebutuhan untuk membuat keputusan pembelian benih dengan menggunakan berbagai pertimbangan yang relevan. Berdasarkan penelitian yang telah dilakukan informasi penting yang dibutuhkan petani pada saat memilih benih bersertifikat adalah kualitas benih yang akan digunakan sementara 42 persen petani memilih untuk menggunakan benih nonsertifikat mengganggap bahwa harga benih merupakan informasi penting yang harus mereka ketahui sebelum membeli benih yang akan dipakai. Persentase terbesar dari bahan yang menjadi pertimbangan petani dalam menggunakan benih bersertifikat adalah mengikuti petani lain karena petani benih bersertifikat lebih percaya bukti yang telah dilihat langsung dari petani lain yang telah menggunakan. Alasan lain mengapa petani dengan mudah mengikuti petani lain dalam memilih benih yang mereka pakai dikarenakan petani lain yang memberikan pengaruh dianggap lebih mempunyai pengalaman. Sedangkan pemilihan benih nonsertifikat dipiih petani karena informasi dari pedagang yang menyatakan bahwa benih yang dipakai lebih laku di pasaran. Data dari tahap evaluasi alternatif dapat dilihat pada Tabel 4.

Tahap berikutnya petani akan membangun niat untuk memilih dan memutuskan untuk membeli benih yang akan digunakan. Tahap ini dinamakan tahap keputusan pembelian. Data dari petani menunjukkan bahwa pada tahap ini petani lebih dominan merencanakan terlebih dahulu sebelum melakukan pembelian benih. Sebanyak 100 persen petani dengan benih sertifikat dan 78 persen petani dengan benih nonsertifikat melakukan perencanaan terlebih dahulu sebelum melakukan pembelian benih. Perencanaan diperlukan oleh petani karena benih yang tidak selalu tersedia di lapangan terutama bagi petani pengguna benih bersertifikat karena untuk mendapat benih terdapat beberapa prosedur yang harus dilakukan oleh petani. Sedangkan yang paling berpengaruh 
dalam proses pembelian yang dilakukan oleh petani yang menggunakan benih sertifikat dengan benih nonsertifikat adalah diri sendiri dengan persentase masing-masing sebesar 86 persen dan 62 persen. Dalam memilih sumber benih yang dipakai 72 persen petani memilih untuk membeli benih bersertifikat dari petani lain yang sudah berpengalaman sebelumnya. Hal ini dilakukan oleh petani karena sulitnya prosedur pembelian benih bersertifikat bagi sebagian petani. Sedangkan $64 \%$ petani pengguna benih nonsertifikat lebih memilih tengkulak benih sebagai sumber benih yang akan dipakai untuk berusahatani. Tengkulak benih terkadang mengklaim bahwa produk mereka berasal dari produsen benih resmi sehingga banyak petani yang tertipu dengan benih palsu yang diedarkan oleh tengkulak benih. Jarak merupakan salah satu alasan dari petani untuk tidak membeli secara langsung atau tidak benih yang akan digunakan. Sebanyak 42 persen petani rela untuk menempuh jarak lebih dari $10 \mathrm{~km}$ untuk mendapatkan benih bersertifikat sementara sebesar 70 persen petani menggunakan benih nonsertifikat lebih menyukai jarak pembelian 1-5 km. Tabel 5 meyajikan secara lengkap data dari tahap keputusan pembelian.

Tabel 4. Tahap Evaluasi Alternatif

\begin{tabular}{|c|c|c|c|c|c|}
\hline \multirow[t]{2}{*}{$\overline{\text { No }}$} & \multirow[t]{2}{*}{ Uraian } & \multicolumn{2}{|c|}{ Petani Benih Bersertifikat } & \multicolumn{2}{|c|}{$\begin{array}{l}\text { Petani Benih } \\
\text { Nonsertifikat }\end{array}$} \\
\hline & & $\begin{array}{c}\text { Jumlah } \\
\text { Responden } \\
\text { (Orang) }\end{array}$ & $\begin{array}{c}\text { Persentase } \\
(\%)\end{array}$ & $\begin{array}{c}\text { Jumlah } \\
\text { Responden } \\
\text { (Orang) }\end{array}$ & $\begin{array}{c}\text { Persentase } \\
(\%)\end{array}$ \\
\hline \multicolumn{6}{|c|}{1 Informasi Penting } \\
\hline & Kualitas & 34 & 68 & & 28 \\
\hline & Produktifitas & 7 & 14 & $\begin{array}{c}14 \\
6\end{array}$ & 12 \\
\hline & $\begin{array}{l}\text { Ketahanan } \\
\text { terhadap HPT }\end{array}$ & - & - & 0 & - \\
\hline & Harga benih & - & - & & 42 \\
\hline & $\begin{array}{l}\text { Ketersediaan } \\
\text { benih }\end{array}$ & 9 & 18 & $\begin{array}{c}21 \\
9\end{array}$ & 18 \\
\hline \multicolumn{6}{|c|}{ 2. Pertimbangan Memilih } \\
\hline & $\begin{array}{l}\text { Kebiasaan yang } \\
\text { telah dilakukan }\end{array}$ & 9 & 18 & 18 & 36 \\
\hline & $\begin{array}{l}\text { Mengikuti } \\
\text { petani lain }\end{array}$ & 30 & 60 & 8 & 16 \\
\hline & Laku di pasaran & 11 & 22 & 24 & 48 \\
\hline
\end{tabular}

$\underline{\text { Tabel 5. Tahap Keputusan Pembelian }}$

\begin{tabular}{|c|c|c|c|c|c|}
\hline \multirow[t]{2}{*}{$\overline{\text { No }}$} & \multirow[t]{2}{*}{ Uraian } & \multicolumn{2}{|c|}{ Petani Benih Bersertifikat } & \multicolumn{2}{|c|}{$\begin{array}{l}\text { Petani Benih } \\
\text { Nonsertifikat }\end{array}$} \\
\hline & & $\begin{array}{c}\text { Jumlah } \\
\text { Responden } \\
\text { (Orang) }\end{array}$ & $\begin{array}{c}\text { Persentase } \\
(\%)\end{array}$ & $\begin{array}{c}\text { Jumlah } \\
\text { Responden } \\
\text { (Orang) }\end{array}$ & $\begin{array}{c}\text { Persentase } \\
(\%)\end{array}$ \\
\hline 1 & $\begin{array}{l}\text { ara Pembelian Benih } \\
\text { a. Terencana } \\
\text { b. Tidak Terencana }\end{array}$ & $\begin{array}{c}50 \\
-\end{array}$ & $\begin{array}{c}100 \\
-\end{array}$ & $\begin{array}{l}39 \\
11\end{array}$ & $\begin{array}{c}78 \\
4\end{array}$ \\
\hline 2 & $\begin{array}{l}\text { Yang berpengaruh } \\
\text { dalam proses } \\
\text { pembelian } \\
\text { a. Diri sendiri } \\
\text { b. Toko } \\
\text { pertanian/pedagang } \\
\text { benih } \\
\text { c. Petani/kelompok } \\
\text { tani } \\
\text { d. Keluarga }\end{array}$ & $\begin{array}{l}43 \\
-\end{array}$ & $\begin{array}{l}14 \\
-\end{array}$ & $\begin{array}{l}31 \\
14\end{array}$ & $\begin{array}{l}62 \\
28\end{array}$ \\
\hline 3. & $\begin{array}{l}\text { Sumber Benih } \\
\text { a.Membuat sendiri } \\
\text { o. Membeli dari petani } \\
\text { lain } \\
\text { c.Koperasi } \\
\text { d. Tengkulak benih }\end{array}$ & $\begin{array}{c}- \\
36 \\
11 \\
3\end{array}$ & $\begin{array}{c}- \\
72 \\
22 \\
6\end{array}$ & $\begin{array}{c}5 \\
13 \\
- \\
32\end{array}$ & $\begin{array}{c}10 \\
26 \\
- \\
64\end{array}$ \\
\hline 4. & $\begin{array}{l}\text { Jarak Tempat } \\
\text { Pembelian Benih } \\
\text { a. } 1-5 \mathrm{~km} \\
\text { b. } \quad 6-10 \mathrm{~km} \\
\text { c. }>10 \mathrm{~km}\end{array}$ & $\begin{array}{l}12 \\
17 \\
21\end{array}$ & $\begin{array}{l}24 \\
34 \\
42\end{array}$ & $\begin{array}{c}35 \\
2 \\
13\end{array}$ & $\begin{array}{c}70 \\
4 \\
26\end{array}$ \\
\hline
\end{tabular}

Tahap terakhir dari proses pengambilan keputusan adalah tahap perilaku pascapembelian. Pada tahap ini, petani sudah membeli dan menggunakan benih sehingga petani sudah mampu melihat dan menilai hasil dari usahataninya. Seluruh petani yang menggunakan benih bersertifikat merasa puas setelah menggunakan benih tersebut tetapi petani yang memilih benih nonsertifikat sebesar 74 persen tidak puas terhadap hasil usahataninya. Kelemahan dari benih nonsertifikat yang dirasakan petani adalah pertumbuhan yang tidak seragam pada saat ditanam dilahan sampai dengan tanaman yang tidak berbuah walaupun sudah ditanam di atas 5 tahun.

Kepuasan yang dirasakan petani pada saat menilai hasil dari benih berdampak pada niat petani untuk membeli kembali benih yang sama. Seluruh petani yang menggunakan benih bersertifikat berniat untuk membeli kembali benih yang pernah mereka pakai sementara 74 persen petani yang menggunakan benih nonsertifikat tidak berminat membeli kembali benih yang mereka pakai walaupun ada yang merasa puas dengan hasil benih. Hal ini disebabkan oleh pengaruh petani lain yang mengganggap bahwa produktivitas akan lebih tinggi bila menggunakan benih lain yang disarankan.

Harga merupakan salah satu faktor penentu keputusan petani dalam membeli benih. 100 persen petani dengan benih bersertifikat akan membeli benih yang sama kembali jika harga benih naik sementara 74 persen petani yang memilih benih nonsertifikat tidak berniat membeli kembali benih yang sudah mereka gunakan. Jika varietas benih yang dipakai tidak tersedia sebanyak 82 persen petani akan memilih benih bersertifikat dengan varietas lain sedangkan 70 persen petani akan memilih varietas lain dari benih nonsertifikat.

Kepuasan petani melihat hasil dari benih yang mereka pakai akan menciptakan loyalitas terhadap benih yang mendorong petani menjadi salah satu sarana promosi yang dapat diandalkan. Petani yang berpengalaman dalam memakai benih akan menjadi pemberi saran bagi petani pemula.100 persen petani bersertifikat menyarankan orang lain untuk membeli benih yang dipakainya sementara 82 persen petani yang menggunakan benih nonsertifikat tidak akan menyarankan kepada orang lain dikarenakan petani kurang merasa puas dengan hasil yang didapat.

Tabel 6. Tahap Perilaku Pasca Pembelian

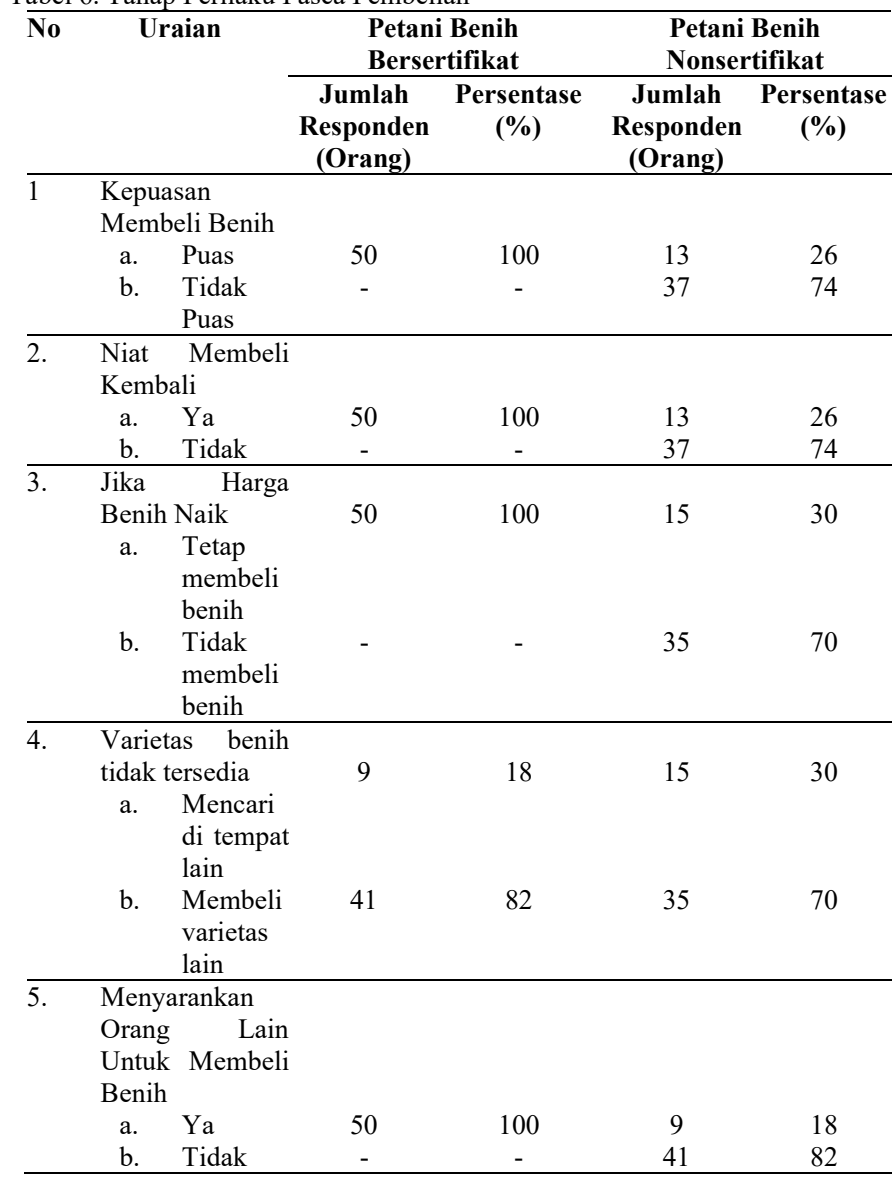

3.3. Faktor-Faktor Yang Mempengaruhi Petani Dalam Membeli Benih Bersertifikat Dan Nonsertifikat

Analisis regresi logistik digunakan untuk mengetahui faktor-faktor yang mempengaruhi pengambilan keputusan petani dalam memilih benih kelapa sawit bersertifikat dan nonsertifikat. Terdapat beberapa variabel yang merupakan faktor yang dapat mempengaruhi keputusan pembelian petani kelapa sawit. Y merupakan variabel terikat pada analisis ini, variabel ini berupa kategorik, dimana petani kelapa sawit yang memilih untuk membeli benih sertifikat diberi nilai 1 dan petani kelapa sawit yang memilih untuk membeli benih nonsertifikat diberi nilai 0. Berdasarkan literatur dan keadaan di lapangan maka dipilih 9 variabel bebas yang akan dianalisis. 9 variabel tersebut adalah pendidikan, pengaruh pihak lain, umur, pengalaman usahatani, luas lahan,persepsi, ketahanan terhadap hama dan penyakit, harga benih, dan akses benih.

Nilai Nagelkerke R square digunakan sebagai parameter ketepatan model. Nilai Nagelkerke $R$ square yang didapat adalah 0,768 . Nilai ini menunjukkan bahwa keragaman variabel bebas dalam menjelaskan keragaman variabel terikat adalah sebesar 76,8 persen sedangkan sisanya sebesar 23,2 persen dijelaskan oleh variabel lain di luar model. Signifikansi dari model dalam memodelkan data diuji dengan uji Goodness-of-fit yang dilakukan dengan menggunakan metode Hosmer-Lemeshow $(H-L)$. Uji dari model menunjukkan hasil bahwa nilai statistik $H$ - $L$ test adalah 5,988 dan nilai p-value atau signifikansi yang dihasilkan adalah 0.649 . Nilai $p$-value yang dihasilkan lebih besar dari taraf nyata 5 persen. 
Hasil tersebut menunjukkan bahwa model logit tersebut layak untuk digunakan karena secara keseluruhan mampu menjelaskan atau memprediksi keputusan petani dalam menggunakan benih kelapa sawit.

Pada tingkat kepercayaan 95 persen $(\alpha=5 \%)$, hasil dugaan model regresi menunjukkan bahwa terdapat tiga variabel yang memberikan pengaruh nyata terhadap keputusan petani memilih benih kelapa sawit, yaitu variabel pendidikan, variabel ketahanan benih terhadap hama dan penyakit tanaman serta variabel harga. Hasil pengolahan data dari regresi logistik dapat dilihat pada Tabel 7 .

\begin{tabular}{lcccccc} 
Tabel 7. Hasil Analisis Regresi Logistik \\
\hline No Variabel & B & S.E & Wald & df & Sig. & Exp(B) \\
\hline 1 Pendidikan & -.099 & 1.548 & .004 & 1 & .949 & .906 \\
2 Pengaruh & -.217 & .807 & .072 & 1 & .788 & .805 \\
$\quad$ Pihak Lain & & & & & & \\
3 Umur & 5.103 & 2.380 & 4.598 & 1 & .032 & 164.585 \\
4 Lama & 3.422 & 1.098 & 9.706 & 1 & .002 & .033 \\
$\quad$ Berusaha Tani & & & & & & \\
5 Luas Lahan & 1.450 & .612 & 5.607 & 1 & .018 & 4.262 \\
6 Persepsi & 22.634 & 10081.4 & .000 & 1 & .998 & 67614095.214 \\
7 HPT & 2.537 & .937 & 7.335 & 1 & .007 & 12.642 \\
8 Harga & .050 & .270 & .034 & 1 & .853 & 1.051 \\
9 Akses Benih & 1.936 & .545 & 12.601 & 1 & .0001 & 6.931 \\
\hline Constant & - & 10081.4 & .000 & 1 & .997 & 000 \\
\hline
\end{tabular}

Variabel umur memiliki nilai signifikansi sebesar 0,032. Nilai ini menunjukkan bahwa variabel pendidikan mempengaruh signifikan terhadap keputusan petani dalam memilih benih kelapa sawit. Variabel ini memiliki koefisien positif, berarti peluang petani menggunakan benih bersertifikat berpengaruh positif dengan umur, dengan kata lain semakin tua umur maka kemungkinan petani menggunakan benih kelapa sawit bersertifikat semakin besar. Umur mempengaruhi kemampuan seseorang dalam bekerja baik secara fisik maupun pikiran. Hasil yang sama juga ditunjukkan oleh penelitian yang dilakukan oleh Valentina Theresia di kota Cirebon pada komoditas bawang merah. Nilai odds ratio pada variabel pendidikan adalah 164,5 , hal ini menunjukkan bahwa peningkatan usia selamal tahun akan meningkatkan keputusan penggunaan benih kelapa sawit sebesar 164,5 kali (cateris paribus).

Variabel lama berusaha tani merupakan variabel selanjutnya yang mempunyai pengaruh yang signifikan terhadap keputusan petani dalam memilih benih bersertifikat. Nilai signifikansi dari varibel ini sebesar 0.002 dengan koefisien yang positif. Koefisien positif dari variabel ini menunjukkan bahwa semakin lama petani berusaha tani maka semakin besar peluang petani untuk membeli benih bersertifikat. Nilai odds ratio pada variabel pendidikan adalah 0.033, hal ini menunjukkan bahwa setiap ada peningkatan pengalamam berusahatani petani maka keputusan penggunaan benih kelapa sawit untuk membeli benih akan meningkat sebesar 0.033 kali (cateris paribus). Hasil ini sama dengan hasil penelitian yang dilakukan oleh Ginanjar pada komoditas jagung di Majalengka pada tahun 2017.

Variabel luas lahan memiliki nilai signifikansi sebesar 0.018, sehingga variabel ini berpengaruh signifikan pada taraf $\alpha=5 \%$ terhadap keputusan pembelian petani dalam memilih benih kelapa sawit bersertifikat. Variabel ini memiliki koefisien positif, berarti peluang petani menggunakan benih bersertifikat berpengaruh positif dengan luas lahan, dengan kata lain semakin luas lahan yang dimiliki petani maka kemungkinan petani menggunakan benih kelapa sawit bersertifikat semakin besar. Nilai odds ratio pada variabel pengaruh dari pihak lain sebesar 4.262 yang berarti bahwa setiap ada penambahan luas lahan maka peluang petani untuk membeli benih kelapa sawit bersertifikat akan meningkat sebesar 4.262 kali. Hal ini sejalan dengan penelitian yang dilakukan oleh Theresia pada tahun 2016 dengan komoditas bawang merah.

Variabel ketahanan terhadap hama dan penyakit tanaman merupakan variabel selanjutnya yang mempunyai pengaruh yang signifikan terhadap keputusan petani dalam memilih benih bersertifikat. Nilai signifikansi dari varibel ini sebesar 0.007 dengan koefisien yang positif. Koefisien positif dari variabel ini menunjukkan bahwa semakin tinggi ketahanan benih kelapa sawit terhadap hama dan penyakit maka semakin besar peluang petani untuk membeli benih bersertifikat. Nilai odds ratio pada variabel pendidikan adalah 12.642, hal ini menunjukkan bahwa semakin tinggi ketahanan benih terhadap hama dan penyakit akan meningkatkan keputusan penggunaan benih kelapa sawit sebesar 12.642 kali (cateris paribus). Ketahanan terhadap hama dan penyakit merupakan salah satu kriteria penting dari benih yang akan digunakan petani terutama bagi petani yang akan melakukan replanting.

Variabel akses benih memiliki nilai signifikansi sebesar 0.0001, sehingga variabel ini berpengaruh signifikan pada taraf $\alpha=5 \%$ terhadap keputusan pembelian petani dalam memilih benih kelapa sawit bersertifikat. Variabel ini memiliki koefisien positif, berarti peluang petani menggunakan benih bersertifikat berpengaruh positif dengan akses benih, dengan kata lain semakin mudah akses benih maka kemungkinan petani menggunakan benih kelapa sawit bersertifikat semakin besar. Hasil yang diperoleh pada penelitian ini sejalan dengan hasil penelitian yang dianalisis oleh Merry Prafithiasari pada tahun 2017 pada benih padi di Kecamatan Warungkondang. Nilai odds ratio pada variabel akses benih sebesar 6.931 yang berarti bahwa semakin mudah benih didapatkan maka peluang petani untuk membeli benih kelapa sawit bersertifikat akan meningkat sebesar 6.931 kali.

\section{Simpulan}

Pada tingkat kepercayaan 95 persen $(\alpha=5 \%)$, hasil dugaan model regresi menunjukkan bahwa terdapat lima variabel yang memberikan pengaruh nyata terhadap keputusan petani memilih benih kelapa sawit, yaitu variabel umur, lama berusaha tani, luas lahan, ketahanan terhadap hama dan penyakit, dan akses benih.

\section{Pustaka}

Afrizon, Renol. 2012. Peningkatan Perilaku Berkarakter dan Ketrampilan Berpikir Kritis Siswa Kelas IX MTsN Model Padang pada Mata Pelajaran IPAFisika. Jurnal Penelitian Pembelajaran Fisika 1 (1).

Asih, Dewi Nur. 2009. Analisis Karakteristik dan tingkat Pendapatan bawang Merah di Sulawesi Tengah Agrolan-. Jurnal Ilmu- Ilmu Pertanian, 16(1): 53-59.

Bakir, S.Z., \& Manning, C. 1984. Angkatan Kerja Di Indonesia: partisipasi, kesempatan, dan pengangguran. Diterbitkan untuk Pusat Penelitian Kependudukan UGM [oleh] Rajawali.

Emiria, F. dan H. Purwandari. 2014. Pengembangan pertanian organik di Kelompok Tani Madya, Desa Kebonagung, Kabupaten Bantul, Daerah Istimewa Yogyakarta. Jurnal Penyuluhan 10 (2).

Direktorat Jendral Perkebunan.2015. Statistik Perkebunan Indonesia. Jakarta. Kementerian Pertanian.

Direktorat Jendral Perkebunan.2019. Pojok Media. Jakarta. Kementerian Pertanian.

Engel, James F, R.D Blackweel, P.J. Winiard. 1995. Perilaku Konsumen, Jilid 1. Jakarta: Bina Rupa aksara.

Ginanjar, G., Andayani, S.A \& Dinar. 2017. Analisis Faktor-Faktor yang Mempengaruhi Pengambilan Keputusan Petani Melakukan Usahatani Jagung Hibrida (Zea mays L). Jurnal Ilmu pertanian dan Peternakan, 5(02): $130-136$

Gomez, K.A. \& Gomez, A.A. 1984. Statistical Procedures for Agricultural Research. Kefamenanu: John Wiley \& Sons.

Joni, M.M.A, M.F.R. Rubzen, and P.J.Batt. 2001. Factors influencing a farmer's decision to purchase seed potatoes in East Java. Paper presented at the 45th Annual Conference of the Australian Agricultural and Resource Economics Society, Adelaide, South Australia.

Kariyasa, I Ketut. 2015. Analisis Kelayakan finansial penggunaan ibit bersertifikat kelapa sawit di Provinsi Kalimantan barat.. Jurnal Agro Ekonomi, 3(2): 141-159

Kotler, P. dan Kevin Lane Keller. 2007. Manajemen Pemasaran Edisi 12. Jakarta: Indeks.

Kotler, P. dan Garry Amstrong. 2016. Principles of Marketing. Pearson Education. England.

Pinem, J. P., \& Saprida.2018. Analisis Pengambilan Keputusan Pembelian Petani dalam Memilih Benih Kelapa Sawit Bersertifikat dan Non Sertifikat di Kabupaten Labuhan Batu Utara. Journal of Agribusiness Sciences 2 (1).

Prafithriasari, M \& G. Fathiyakan. 2017. Analisis Sikap dan Keputusan Petan dalam Menggunakan Benih Padi Varietas Lokal Pandanwangi. Jurnal Agroscience 7(2).

Schiffman and Kanuk. 2008. Perilaku Konsumen Ed 7. Jakarta: PT. Indeks.

Sumarwan, U. 2004. Perilaku Konsumen: Teori Dan Penerapannya Dalam Pemasaran. Ghalia Indonesia. Bogor.

Sumarwan, U. 2010. Perilaku Konsumen. PT Ghalia Indonesia, Anggota IKAPI, Bogor.

Theresia,V., Anna. F \& Netti T. 2016. Pengambilan Keputusan Petani Terhadap Penggunaan Bawang Merah Lokaldan Impor di Cirebon, Jawa Barat.Jurnal Agraris 2(1) 